University of Nebraska - Lincoln

DigitalCommons@University of Nebraska - Lincoln

USDA National Wildlife Research Center - Staff Publications
U.S. Department of Agriculture: Animal and Plant Health Inspection Service

January 2005

\title{
Slow migration of capsicum oleoresin in a sandy loam soil
}

Ray T. Sterner

USDA, APHIS, Wildlife Services, National Wildlife Research Center

Bruce A. Kimball

USDA, APHIS, Wildlife Services, National Wildlife Research Center, bruce.kimball@ars.usda.gov

Follow this and additional works at: https://digitalcommons.unl.edu/icwdm_usdanwrc

Part of the Environmental Sciences Commons

Sterner, Ray T. and Kimball, Bruce A., "Slow migration of capsicum oleoresin in a sandy loam soil" (2005). USDA National Wildlife Research Center - Staff Publications. 56.

https://digitalcommons.unl.edu/icwdm_usdanwrc/56

This Article is brought to you for free and open access by the U.S. Department of Agriculture: Animal and Plant Health Inspection Service at DigitalCommons@University of Nebraska - Lincoln. It has been accepted for inclusion in USDA National Wildlife Research Center - Staff Publications by an authorized administrator of DigitalCommons@University of Nebraska - Lincoln. 


\title{
Note \\ Slow migration of capsicum oleoresin in a sandy loam soil
}

\author{
Ray T. Sterner*, Bruce A. Kimball \\ USDA, APHIS, Wildife Services, National Wildlife Research Center, 4101 LaPorte Avenue, Fort Collins, CO 80521-2154, USA
}

\begin{abstract}
A mixture of $16.47 \pm 0.038 \mathrm{~L}$ concentrated capsicum oleoresin with $163.8 \pm 3.63 \mathrm{~L}$ water and a total of $17.2 \mathrm{~L}$ concentrated soybean oil with $177.1 \mathrm{~L}$ water was dispensed over five $4.87 \mathrm{~m} \times 4.87 \mathrm{~m}$ plots via a grid of 128 augured holes $(\approx 15 \mathrm{~cm}$ diameter $x \approx 30 \mathrm{~cm}$ deep) in a compacted, sandy loam soil. During the next 9 days, a total of 37 soil samples were obtained from these plots and other off-plot areas. Spectrophotometric analyses of dual aliquots of soil samples were performed to detect absorbance of capsaicin $\left(\lambda_{\max }\right.$ at $\left.282 \mathrm{~nm}\right)$. Analysis of variance showed that absorbance readings from points of capsicum application (augured holes) were 30-fold greater than for samples obtained $30-40 \mathrm{~cm}$ distant $(F=19.21$, df $1 / 4.22$, $p<0.0105)$. Soybean-oil plot and off-plot soil samples yielded negligible absorbance readings. Thus, capsicum oleoresin persisted for $\geqslant 10$ days in this type of soil, but migration was minimal.
\end{abstract}

Published by Elsevier Ltd.

Keywords: Capsicum oleoresin; Detection; Migration; Soil; Spectrophotometry; Absorbance

\section{Introduction}

Capsaicin (CAS no. 404-86-4) is a biochemical pesticide (US Environmental Protection Agency, 1992a, b). This naturally occurring, non-carcinogenic substance is obtained by grinding dried chili peppers (Capsicum frutescens L.) and formulating these particles in liquid, aerosol or other carrier; the oleoresin form (CAS no. 8023-77-6) is made by distilling the powdered active ingredient (AI) in a solvent and evaporating the solvent, then preparing a liquid using a carrier, e.g., soybean oil.

Capsaicin-based products are gaining widespread use as animal repellents (see Mason et al., 1996; Mason, 1997; Baker et al., 1999). Some registered compounds are Counter Assault ${ }^{\circledR}$, Deer Away ${ }^{\circledR}$, Hinder ${ }^{\circledR}$ and Hot Sauce ${ }^{\circledR}$. Repellent action assumes that this irritant is delivered in sufficient concentration/exposure to permeate tissue (e.g., oral and nasal mucosa, and dermal) and to depolarize pain receptors (Bryant, 1997). Capsicum oleoresin causes depolarization (pain) by stimulating

\footnotetext{
*Corresponding author. Tel.: + 19702666170 ; fax: +19702666157 .

E-mail address: ray.t.sterner@aphis.usda.gov (R.T. Sterner).
}

nociceptors (sensory receptor cells) owing to either thermal, mechanical or chemical insult (Bryant, 1997).

Capsaicin and capsicum oleoresin are generally considered safe chemicals. The probable oral lethal dose for diverse mammalian species ranges between 0.5 and $5 \mathrm{~g} \mathrm{~kg}^{-1}$ (Gosselin et al., 1976). The chemical is used medicinally in humans as a $0.075 \%$ cream, prescribed for pain following shingles (US Pharmacopeal Convention, 1994). Nevertheless, debilitating respiratory distress, lacrimation, and mucosa burning from concentrates must be noted; and the inadvertent (but unlikely) consumption of the concentrated AI could prove fatal.

Searches of chemical-environmental databases yielded few articles dealing with fate or residue data relevant to capsaicin or capsicum oleoresin (A. Noble and J. Eisemann, USDA/APHIS/WS National Wildlife Research Center, personal communication, 2001; L. Paulik, USDA/APHIS/WS National Wildlife Research Center, personal communication, 2005). Increased development and use of capsaicin-based animal repellents is viewed as a precursor of more regulatory requirements for environmental fate of these residues.

Recently, Sterner et al. (1999) showed that mixing $\geqslant 1.50 \% \quad(\mathrm{w} / \mathrm{w})$ capsicum oleoresin in soil during 
laboratory exposures reduced the soil-contact time by northern pocket gophers by about $50 \%$ relative to placebo-exposed animals. The capsicum-soil-exposed gophers spent roughly $50 \%$ less time on the treated soil, i.e. clean platform, than animals exposed to placebo (moist) soil. Moreover, grooming time increased for capsicum-exposed gophers; this effect indirectly reduced both their digging time and their digging bouts (Sterner et al., 1999). In a later persistence study, soil concentrations of $6.00 \%, 3.00 \%, 1.50 \%$ and $0.75 \%$ capsicum $(\mathrm{w} / \mathrm{v})$ were depleted rapidly during 14 consecutive days of $0.64 \mathrm{~mL} \mathrm{~cm}^{-2} \mathrm{day}^{-1}$ simulated rainfall, but these concentrations stabilized and remained unchanged during an additional 14 days without water applications (Sterner et al., 2002).

This paper describes the use of an absorbance method to detect and monitor migration of capsicum oleoresin in a compacted sandy loam soil under field conditions. The persistence of repellents is crucial to the development of effective in-soil methodology for rodents.

\section{Methods and materials}

The study site was a 64.75 ha alfalfa (Medicago sativa) field located $\approx 20 \mathrm{~km}$ northwest of Wellington, Colorado. The field was irrigated using an overhead rotating pivot system and had a mature stand of alfalfa. Soil analysis revealed that the very compacted jsoil at the site was a sandy loam $(62 \%$ sand, $26 \%$ silt, $12 \%$ clay, $2.5 \%$ organic matter; $\mathrm{pH}$ 7.9) (Agvise Laboratories, Northwood, ND).

Capsicum oleoresin was obtained as a dark red, viscous liquid (Penta Manufacturing Co., Livingston, NJ; CAS No. 8023-77-6; Mfg. No. 03-09000; Lot No. 46051 and 52577). The manufacturer reported that the material assayed at 1,000,039 Scoville Units, contained $4.92 \%$ capsinoids, and had a soybean oil base (see Hoffman et al., 1983). The soybean oil (placebo) was obtained from a commercial food-products supplier.

Five $4.87 \mathrm{~m} \times 4.87 \mathrm{hym}$ plots were prepared. Four were treated with capsicum oleoresin and one was treated with soybean oil (placebo). Plots were randomly assigned to conditions.

Prior to chemical application, alfalfa was cut to a height of $\approx 2.54 \mathrm{~cm}$ and removed from each plot. Next, each plot surface was lined out in $256(16 \times 16)$ equalsized grids $-30.5-\times 30.5-\mathrm{cm}$ cells. The centres of alternate cells (checker-board style) were then marked with a spot of non-toxic paint, and $\approx 15 \mathrm{~cm}$ diameter holes $\approx 0.45 \mathrm{~m}$ deep were dug at these spots using a gaspowered auger. Some auger holes intersected tunnels made by Northern pocket gophers (Thomomys talpoides); most of these tunnels were traversed/used by gophers at the time of chemical insertion.

Chemical application involved placing quantities of capsicum oleoresin or soybean oil concentrate into each augured hole, and pumping water into holes via a commercial gas-powered pump and tank system (Hypro Roller Pump, Mdl. 7560N, Pest Control Supplies, Kansas City, MO). Calibration trials showed that gauge settings of 90,150, and 210 psi pump pressure provided mean volume outputs of $5.1,7.6$, and $9.2 \mathrm{~L} \mathrm{~min}^{-1}$, respectively. We sought to place $170 \mathrm{~L}$ of a $10: 90(\%)$ capsicum oleoresin or soybean oil and water mixture onto each plot. Thus, $43.5 \mathrm{~mL}$ capsicum oleoresin or soybean oil concentrate was dispensed into each augured hole that did not intersect a rodent tunnel and then diluted with $435 \mathrm{~mL}$ of water $(10: 90 \% \mathrm{v} / \mathrm{v}$ mixture); the remaining quantity was dispensed equally among the number of augured-holes that intersected rodent tunnels (see Table 1). Onto four plots a mean $( \pm \mathrm{SD})$ of $16.47 \pm 0.038 \mathrm{~L}$ concentrated capsicum oleoresin was dispensed, and $163.8 \pm 3.63 \mathrm{~L}$ water; whereas, a total of $17.2 \mathrm{~L}$ of concentrated soybean oil and $177.1 \mathrm{~L}$ of water was dispensed onto the soybean oil (placebo) plot.

The study was conducted between August 22 and September 2, 1999. Alfalfa was cut/removed from plots on August 22. Plots were prepared for chemical applications (holes augured) on August 23. Capsicum oleoresin and placebo (soybean oil) applications were on separate days, August 24 and 25, respectively. Soil samples were collected from the capsicum oleoresin plots on August 25, 27, 29 and September 2, and from

Table 1

Chemical application data for capsicum oleoresin:water and soybean oil:water by plots

\begin{tabular}{|c|c|c|c|c|c|c|c|c|c|}
\hline Chemical & Plot & $\begin{array}{l}\text { Augered } \\
\text { holes (no.) }\end{array}$ & $\begin{array}{l}\text { Augered holes } \\
\text { with tunnel- } \\
\text { intersects (no.) }\end{array}$ & $\begin{array}{l}\text { Soybean oil } \\
\text { or capsicum } \\
\text { in augered } \\
\text { holes }(\mathrm{L})\end{array}$ & $\begin{array}{l}\text { Water in } \\
\text { augered } \\
\text { holes }(\mathrm{L})\end{array}$ & $\begin{array}{l}\text { Soybean oil } \\
\text { or capsicum } \\
\text { in tunnel- } \\
\text { intersects }(\mathrm{L})\end{array}$ & $\begin{array}{l}\text { Water in } \\
\text { tunnel- } \\
\text { intersects (L) }\end{array}$ & $\begin{array}{l}\text { Total volume } \\
\text { (water + soybean } \\
\text { oil or capsicum) } \\
\text { (L) }\end{array}$ & $\begin{array}{l}\text { Proportion } \\
\text { of mix }(\%)\end{array}$ \\
\hline \multirow[t]{4}{*}{ Capsicum } & le & 111 & 17 & 4.8 & 48.2 & 11.9 & 118.2 & 183.1 & 9.1 \\
\hline & $2 \mathrm{e}$ & 114 & 14 & 5.0 & 49.5 & 11.2 & 109.5 & 175.2 & 9.2 \\
\hline & $3 e$ & 109 & 19 & 4.7 & 47.4 & 11.4 & 115.6 & 179.1 & 9.0 \\
\hline & $4 \mathrm{e}$ & 113 & 15 & 4.9 & 49.1 & 12.0 & 117.7 & 183.7 & 9.2 \\
\hline Mean \pm SD & & $111.7 \pm 2.2$ & $16.2 \pm 2.2$ & $4.85 \pm 0.1$ & $48.5 \pm 0.9$ & $11.6 \pm 0.4$ & $115.2 \pm 4.0$ & $180.3 \pm 3.9$ & \\
\hline Soybean oil & $1 p$ & 107 & 21 & 4.6 & $46.5^{-}$ & 12.6 & 127.8 & 191.5 & 9.0 \\
\hline
\end{tabular}


the soybean oil plot on August 31. Soil sampling from off-plot locations occurred on each of these days.

A total of 37 core samples $(25-45 \mathrm{~cm}$ depth) were obtained using a tapered soil-sampling tube $(152.4 \mathrm{~cm}$ long; $4.1 \mathrm{~cm}$ diameter orifice). Each was emptied into a separate, clean, pre-labelled (plot, location and date), $3.8 \mathrm{~L}$ plastic bag and stored in a dry plastic picnic cooler. Thirteen samples were removed from augured holes (chemical-application points) in the plots, 14 samples were removed from spots located between 30 and $40 \mathrm{~cm}$ distant from the augured holes in the plots, and eight samples were removed from off-plot spots located $>2 \mathrm{~m}$ away from the plots.

Analyses of soil samples for capsaicin were performed using the methods outlined in Sterner et al. (2002) and equipment/methods given in Owen (1988). The soil analyses involved a single-blind procedure; each sample was re-numbered from 1 to 37 so that the analyst did not know the location from which a sample was obtained.

Mean absorbance (AU) readings obtained at $282 \mathrm{~nm}$ for dual aliquots of soil samples on capsicum oleoresin plots were analyzed using PROC MIXED analysis of variance (SAS Institute, 1992). Plot was considered a random-effects variable, and soil-sampling point was considered a fixed-effects variable - the difference between AU readings of on-plot samples obtained at augured holes (i.e. direct chemicals applied) and $30-40 \mathrm{~cm}$ distant from augured holes was tested as a one-way design (Winer, 1971). For statistical analysis, negative AU measurements were set to zero. The AU readings from the soybean plot (placebo) and off-plot (control) samples were treated descriptively. The AU readings were also compared to those obtained in a controlled laboratory experiment of the persistence of capsicum oleoresin (see Sterner et al., 2002).

\section{Results and discussion}

Analysis of variance of AUs showed that capsicum oleoresin residues in soil samples at augured hole application points were greater than those for samples obtained 30-40 $\mathrm{cm}$ away from these points $(F=19.21$, df $1 / 4.22, p<0.0105)$. Mean \pm SD AU readings for soil samples from augured holes and $30-40 \mathrm{~cm}$ away from these application points were $0.0619 \pm 0.0412$ and $0.0019 \pm 0.0020$, respectively (Fig. 1). This represents roughly a 30 -fold greater quantity of capsaicin at points of application, and little evidence of $30-40 \mathrm{~cm}$ movement of the chemical from these points within the 9-day sampling period. Soil samples from the soybean plot and off-plot sites yielded extremely low AU readings. The mean AUs for soybean soil application point samples was $0.0097 \pm 0.0100$; whereas, a single detection for $30-40 \mathrm{~cm}$ away from these points was null (0.0000 AU). Mean off-plot samples yielded $0.0008 \pm 0.0015$ AU.

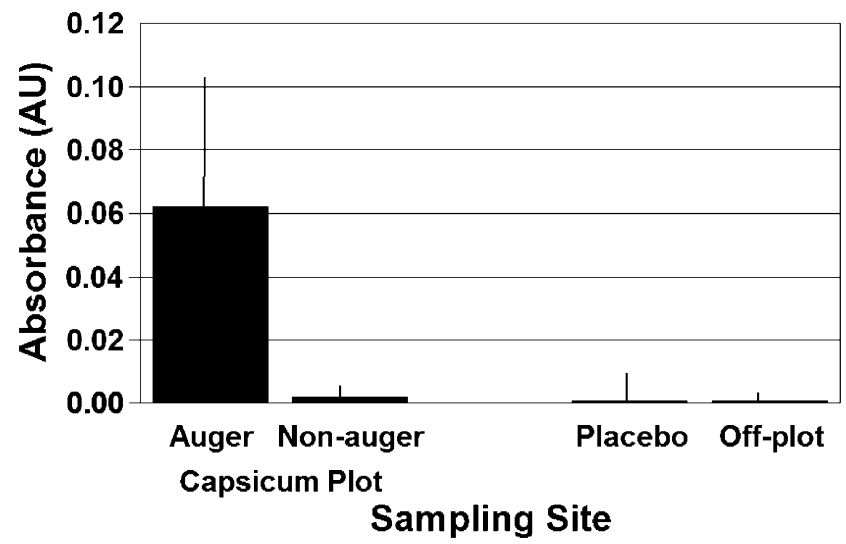

Fig. 1. Graph of mean absorbance readings for soil samples collected from capsicum oleoresin plots at auger holes and $30-40 \mathrm{~cm}$ away from auger holes, plus on soybean oil plots and at off-plot locations.

Sterner et al. (2002) showed that mean (SD) AU values of $0.150(0.032), 0.262(0.045), 0.714(0.017)$, and $1.200(0.064)$ coincided with roughly $0.75 \%, 1.50 \%$, $3.00 \%$, and $6.00 \%(\mathrm{w} / \mathrm{v})$ mixtures of capsicum oleoresin. Thus, current samples at the point of application would be estimated as being considerably less than $0.75 \%$ capsicum oleoresin, with concentrations at capsicum plots $\geqslant 29 \mathrm{~cm}$ from the point of application essentially undetected. Soybean oil plot and off-plot points were also essentially nil capsaicin. Data for gophers showed that insertion of the capsicum mixture caused only temporary movement of animals away from chemical application points (see Sterner et al., 2005). Counts of on- and off-plot mounds of excavated fresh soil by gophers (i.e. sign of new tunnels) near capsicum application areas were equivocal.

Persistence of capsicum oleoresin in soil has been demonstrated, especially under conditions of low precipitation (Sterner et al., 2002), but the bacterium Pseudomonas maltophilia has been shown to speed decomposition of capsaicin to vanilyllamine (see Onozaki et al., 1985, 1986). Although we suspect that capsicum oleoresin will leach rapidly in loose, sandy loam soils under moderate rainfall, the compacted soils at this site made it doubtful that leaching due to adsorption, dispersion, or water infiltration/evaporation could have affected our results. In fact, our soil residue data support the observation that capsicum oleoresin remained present in or near augured holes throughout the post-application period. We also believe that our capsaicin-detection method offers a relatively simple, effective technique of monitoring the decomposition or movement of these products in soil media.

\section{Acknowledgments}

Kenneth Crane, Todd Felix, Brett Petersen and Stanley Gaddis provided technical support; Abbe Ames 
performed the soil residue analyses; Richard Engeman provided statistical consultation; Kathleen Fagerstone and Craig Ramey made helpful edits of the draft manuscript.

\section{References}

Baker, D.L., Andelt, W.F., Burnham, K.P., Shepperd, W.D., 1999. Effectiveness of Hot Sauce ${ }^{\circledR}$, and Deer Away ${ }^{\circledR}$ repellents for deterring elk browsing on aspen trees. Journal of Wildlife Management 63, 1327-1336.

Bryant, B.P., 1997. Peripheral trigeminal neural processes involved in repellency. In: Mason, J.R. (Ed.), Repellents in Wildlife Management. US Department of Agriculture, National Wildlife Research Center, Fort Collins, CO, pp. 19-28.

Gosselin, R.E., Hodge, H.C., Smith, R.P., Gleason, M.N., 1976 Clinical Toxicology of Commercial Products. vol. 2, fourth Ed., Williams and Wilkins, Baltimore, MD. p.145

Hoffman, P.G., Lego, M.C., Galetto, W.G., 1983. Separation and quantitation of red pepper major heat principles by reverse-phase high-pressure liquid chromatography. Journal of Agricultural and Food Chemistry 31, 1326-1330.

Mason, J.R. (Ed.), 1997. Repellents in wildlife management. US Department of Agriculture, National Wildlife Research Center, Fort Collins, CO, p. 463pp.

Mason, J.R., Nolte, D.L., Bryant, R.P., 1996. Effectiveness of thirteen vertebrate repellents as rodent trigeminal stimulants. Physiology and Behavior 64, 1449-1452.
Onozaki, H., Isshiki, S., Esaki, H., 1985. Decomposition of capsaicin to vanillyamine by Pseudomonas spp. Hakkokgaku Kaishi 63, 221-226.

Onozaki, H., Isshiki, S., Esaki, H., 1986. Bacterial metabolism of vanillyamine and vanillin. Hakkokgaku Kaishi 64, 425-430.

Owen, A.J., 1988. The Double-array Advantage in UV/visible Spectroscopy. Publication Number 12-5954-8912, Hewlett-Packard Company 60pp.

SAS Institute, Inc., 1992. The MIXED procedure. SAS/STAT Software: Changes and enhancements. Release 6.11. Cary, NC, pp. 533-656.

Sterner, R.T., Hollenbeck, K.A., Shumake, S.A., 1999. Capsicumladen soils decrease contact time by northern pocket gophers. Physiology and Behavior 67, 455-458.

Sterner, R.T., Ames, A.D., Kimball, B.A., 2002. Persistence of capsicum oleoresin in soil. International Biodeterioration and Biodegradation 49, 145-149.

Sterner, R.T., Shumake, S.A., Gaddis, S.E., Bourassa, J.B., 2005. Development of capsicum oleoresin as an in-soil repellent for pocket gophers. Pest Management Science, in press.

US Environmental Protection Agency, 1992a. Registration Eligibility Document (RED). B. Capsaicin. Office of Prevention, Pesticides, and Toxic Substances (H-7508W) 21-T-100x (June), Washington, DC, 148 pp.

US Environmental Protection Agency, 1992b. R.E.D. Facts - capsaicin. Office of Prevention, Pesticides, and Toxic Substances (H-7508W) 21-T-100x (June), Washington, DC, 4pp.

US Pharmacopeal Convention, 1994. US Pharmacopeal drug indexdrug information for the health care professionals, vol. I, 14th ed. US Pharmacopeal Convention, Incorporated, Rockville, MD.

Winer, B.J., 1971. Statistical Principles in Experimental Design. McGraw-Hill, New York, pp., 149-257. 